\title{
APPLICATION OF OZONE IN GRAIN DRYING: AUTONOMOUS SENSOR SYSTEM CONSTRUCTION AND PECULARITIES
}

\author{
Jānis KLEPERIS, Institute of Solid State Physics, University of Latvia, Raiņa blvd 19-125, LV-1586 Riga, Latvia, kleperis@latnet.lv \\ (corresponding author) \\ Alberts KRISTIN̦Š, Institute of Solid State Physics, University of Latvia, Raiņa blvd 19-125, LV-1586 Riga, Latvia, kristin@latnet.lv \\ Juris VEINBERGS, Institute of Solid State Physics, University of Latvia, Raina blvd 19-125, LV-1586 Riga, Latvia, \\ Irina GVARDINA, Institute of Solid State Physics, University of Latvia, Raina blvd 19-125, LV-1586 Riga, Latvia, \\ Dainis VIESTURS, Latvia University of Life Sciences and Technologies, Lielā iela 2, Jelgava, LV-3001, Latvija, viesturs_uzc@apollo.lv \\ Ādolfs RUCIN̦Š, Latvia University of Life Sciences and Technologies, Lielā iela 2, Jelgava, LV-3001, Latvija, arucins@ltk.lv \\ Evita STRAUMĪTE, Latvia University of Life Sciences and Technologies, Lielā iela 2, Jelgava, LV-3001, Latvija, evita.straumite@1lu.lv \\ Biruta SLOKA, Faculty of Business, Management and Economics of University of Latvia, Raina blvd 19-125, LV-1586 Riga, Latvia, \\ Juris BRŪVERIS, Ltd “Ozone Tech” Robežu 54, Rīga, LV-1002, Latvia
}

The capabilities of modern electronics for autonomous environmental monitoring with wireless data transmission and storage are diverse and give the network operator some freedom in performing any task. The aim of the study is to develop a sensor system for monitoring and controlling the active drying process of grain. An experimental prototype was developed and installed on the farm for two grain drying tanks of the same volume; for one of which the intake air was blended with ozone as a grain drying agent. The paper analyzes the desired and minimum number of monitoring parameters, sensor requirements, their optimal placement in grain drying tanks, data collection, transmission and storage, and data processing and display capabilities. By way of example, the preliminary results of grain drying in tank with ozone-enriched intake air are demonstrated.

Keywords: grain drying, ozone gas sensor, humidity sensor, data transmission.

\section{INTRODUCTION}

Technologies that leave the least impact on the environment are going to increase popular in agriculture. Such a traditional and conservative area as grain cultivation also applies to it. From middle of 20th century studies on the impact of ozone on grains started - that ozone can both replace chemicals for weed control and grain etching, as well as improve grain quality during the drying process.

From one side tropospheric ozone at elevated concentrations is known as a grain harvest degradation agent (Emberson, 2018), from other side ozone has been shown to have antibacterial properties (Avdeeva, 2018; Raila, 2006; Sandhu, 2012; Tiwari, 2010).

Analyzing the scientific studies carried out on the use of ozone in grain processing, it can be concluded that:

a) The quality of different grains is influenced by both the amount of ozone used and the time of ozonation (Sandhu, 2012; Avdeeva, 2018);

b) Ozone is used to provide a microbiologically safe product. Fusarium graminearum is a major pathogen found in cereals, especially wheat and barley (Zhu, 2018). Studies have shown that it is possible to reduce Fusarium graminearum by up to $95 \%$ with ozone treatment for $3 \mathrm{hrs}$. Studies have also shown the ability of ozone to kill various insects, which can be up to $100 \%$ in grains (depending on the type of insect, ozonation time and dose) (Tiwari, 2010). It is important to reduce mycotoxin content in grains, which can also be achieved using ozone (Tiwari, 2010).

c) Ozonation can influence the starch pasteurization process (Sandhu et al., 2012), which is an important factor in the bread making process;

d) The use of ozone can reduce the energy required in the milling process by reducing the amount of outer casing and damaged starch grains (Zhu, 2018).

In our research we have proved that modern sensing transducers for temperature, relative humidity and ozone concentration to collect data from different layers in grain tank during drying process can be used not only in the laboratory but also in the farm under real conditions.

Copyright () 2019 The Authors. Published by Vytautas Magnus University. This is an open-access article distributed under the terms of the Creative Commons Attribution License (CC BY 4.0), which permits unrestricted use, distribution, and reproduction in any medium, provided the original author and source are credited. 


\section{METHODOLOGY OF EXPERIMENTS}

In the experiments, it is intended to ventilate the grains in two equal tanks with the same initial the moisture content. In one tank (ozone tank OT), the generator-produced ozone will be added to the ventilation air taken from outdoor, the other (reference tank RT) will be ventilated with outdoor air. The essence of the experiments: to find out whether the ozone additive to the ventilation air accelerates the removal of moisture from the thick layer of grain and thus shortens the time it takes for the grain to reach defined moisture content. The following parameters are measured during the experiments with sensor systems and hand tools:

1. Power consumption of the fan connected to each tank;

2. Ozone generator power consumption;

3. Air humidity (RH units) in both tanks in grains at intervals of $1 \mathrm{~m}$;

4. Grain moisture content in surface layer of both thanks at beginning and end of drying process;

5. Grain temperature in both tanks at intervals of $1 \mathrm{~m}$;

6. Ozone concentration in the tank OT at intervals of $1 \mathrm{~m}$;

7. Ambient air humidity, temperature, ozone concentration with independent sensor system;

8. Ozone concentration at the inlet to the OT with a separate sensor system (applicable to higher ozone concentrations);

9. Exhaust air velocity over the top grain layer in tank.

\section{Devices and instruments used}

The electricity consumed by the fans and the ozone generator is determined by an appropriate electricity meter connected to each of these consumers. Manual measurements are used as control measurements with handheld ozone device QL-800-O3(QLOZONE, China), grain moisture content meter Wile 66 (FarmComp Oy, Finland).

In first experiments two OPV-100.03 (OOO НПО "Жемчужина Руси", RU, http://www.bakteriy.net/) ozone generators are used with total ozone output $200 \mathrm{~g} / \mathrm{h}$ and power consumption $2 \mathrm{~kW}$.

Sensor systems with two different ozone sensors are selected for tests in grain tank (Fig. 1) - for lower layer with higher ozone concentrations (up to $20 \mathrm{ppm}$ ) $\mathrm{O}_{3}$ transmitter integrated with humidity and temperature sensors from producer (XIN NUO QI, China), and for next layers with sensitivity region 0-10 ppm from www.jnrsmcu.com (China). $\mathrm{x}$

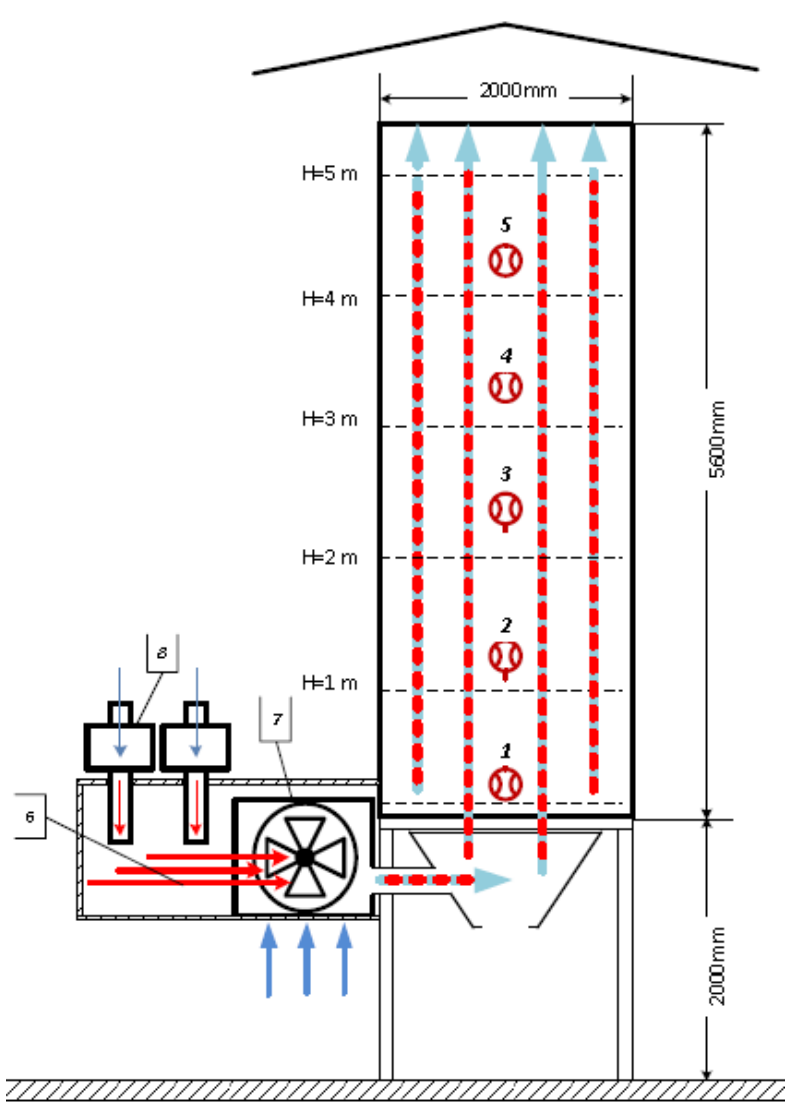

Figure 1. Grain layers in ozone tank OT and positions of sensor systems (1-5); grain processing equipment: ozone intake (6), air supply fan (7), ozone generator (8). 
For RT Sensor systems ${ }^{\circ} \mathrm{T}+\mathrm{RH}$ (RS-WS-N01-2-3) were used for RT and ${ }^{\circ} \mathrm{T}+\mathrm{RH}+\mathrm{O}_{3}$ sensor systems (RS-O3WS-N012-4-10) for OT. For both types the gas detection hole is covered with a polymer gas membrane which is water-tight and can permeate the gas but block the moisture and particles.

The positions of sensor devices in tank are shown in Fig. 1 - the sensor 1 is close to intake air fan where highest ozone concentrations are predicted. $200 \mathrm{~g} \mathrm{O}_{3} / \mathrm{h}$ from output of ozone generator is diluted with air $7200 \mathrm{~m}^{3} / \mathrm{h}$ up to concentration $0.028 \mathrm{~g} \mathrm{O}_{3} / \mathrm{m} 3$ air (corresponds $13.5 \mathrm{ppm}$ ). Over the layers, the ozone concentration will drop an average of $2 \mathrm{x} / 1 \mathrm{~m}$ (Steponavičiene, 2012) and the $10 \mathrm{ppm}$ ozone sensor system could work well. If the air flow rate is reduced, the ozone concentration in the upper layers will increase and these sensor systems will show ozone saturation.

There are different ways to protect the sensors from direct contact with the grain. Author (Chen, 2001) place a compact humidity / temperature sensor in a porous plastic case immersed in grain. It takes some time for the moisture in the surrounding grain to equalize the moisture in the case. We placed the sensors in plastic boxes with holes covered with a fine steel mesh inside, and the boxes with the sensor system power-signal cable are fixed to the $40 \mathrm{~mm}$ diameter plastic pipe at the required height in the middle of the tank with holes for sensor cable entry.

Grain moisture in the tanks is determined with both sensor systems $\left({ }^{\circ} \mathrm{T}+\mathrm{RH}\right.$ and $\left.\mathrm{O}_{3}+{ }^{\circ} \mathrm{T}+\mathrm{RH}\right)$ in different layers of grains and control measurements with grain moisture meter Wile 66. The relative humidity of the air between grains determines the moisture content of the grain. There are several studies in the scientific literature on the use of relative humidity (RH) and temperature (T) sensors to determine the moisture content (MC) of grains. In practice, several experimentally determined equations are used from which most popular is Chung-Pfost equation (see Chen, 2001):

$$
M C=-\frac{1}{B} \ln \left[\frac{-(T+C) \ln (R H)}{A}\right]
$$

where $\mathrm{A}, \mathrm{B}$ and $\mathrm{C}$ are constants determined experimentally for selected brand of grains.

The sensor must be in the grain, and when equilibrium is reached, the relative humidity is proportional to the moisture content of the grains. In this method, the temperature must be corrected for the readings, so the temperature sensor is nearby to the humidity sensor. Modern sensors are sensitive and quickly reach equilibrium, so during drying, if the air changes slowly, both the humidity sensor and the temperature sensor will keep track of the grain moisture.

\section{Circuit and data reading/display/storage/exchange for sensor systems}

The drying process control system consists of the following components (as shown in Fig. 2):

- $\quad$ sensors (5 pieces) in each tank (RT and OT tanks) and a separate outdoor air sensor;

- data storage and transmission modules (one module per tank), which includes a microcontroller with memory, power supply and data transmission-reception module E-32 with antenna;

- a computer with an attached USB converter and an E-32 transceiver module with antenna.

The block diagram of the sensor connections in both tanks (OT and RT) is similar. Microcontroller and connected sensors communicate via RS485 using the MODBUS RTU protocol. The controller requests and receives (every 5 s) information from all connected sensors and can store the data received from the sensors in its memory. The changes of the sensor parameters are only recorded in the microcontroller memory if the difference between the two values isn't less than specified value $\left(0,5^{\circ} \mathrm{C}\right.$ for temperature, $0,5 \%$ for humidity and $0,3 \mathrm{ppm}$ for ozone).

The transmitter-receiver module E-32 is used for data transfer between the controller and the computer. E-32 series modules are UART wireless modules based on SX1276/SX1278 RF IC of SEMTECH with transparent transmission and LoRa spread spectrum technology. The LoRa spread-spectrum means the transmitting distance is much longer. Confidentiality is high and the possibility of being intercepted is extremely low.

When the computer is on, the data collected by the microcontroller is transferred to the computer. The data exchange is requested by the computer every 10 s.

The PC contains server, viewer and administrator programs. The server program connects to date collection systems and operates on a date base (based on Interbase). It also shows the current state of the entire system. The viewer program works with a date base and allows us to see changes in the parameters of the specified sensors in real time mode or during the specified time interval (in the table and graph presentation). This data can be transferred to Excel. The administrator program works also with the database and let see all the events fixed in the database (in selected form). 


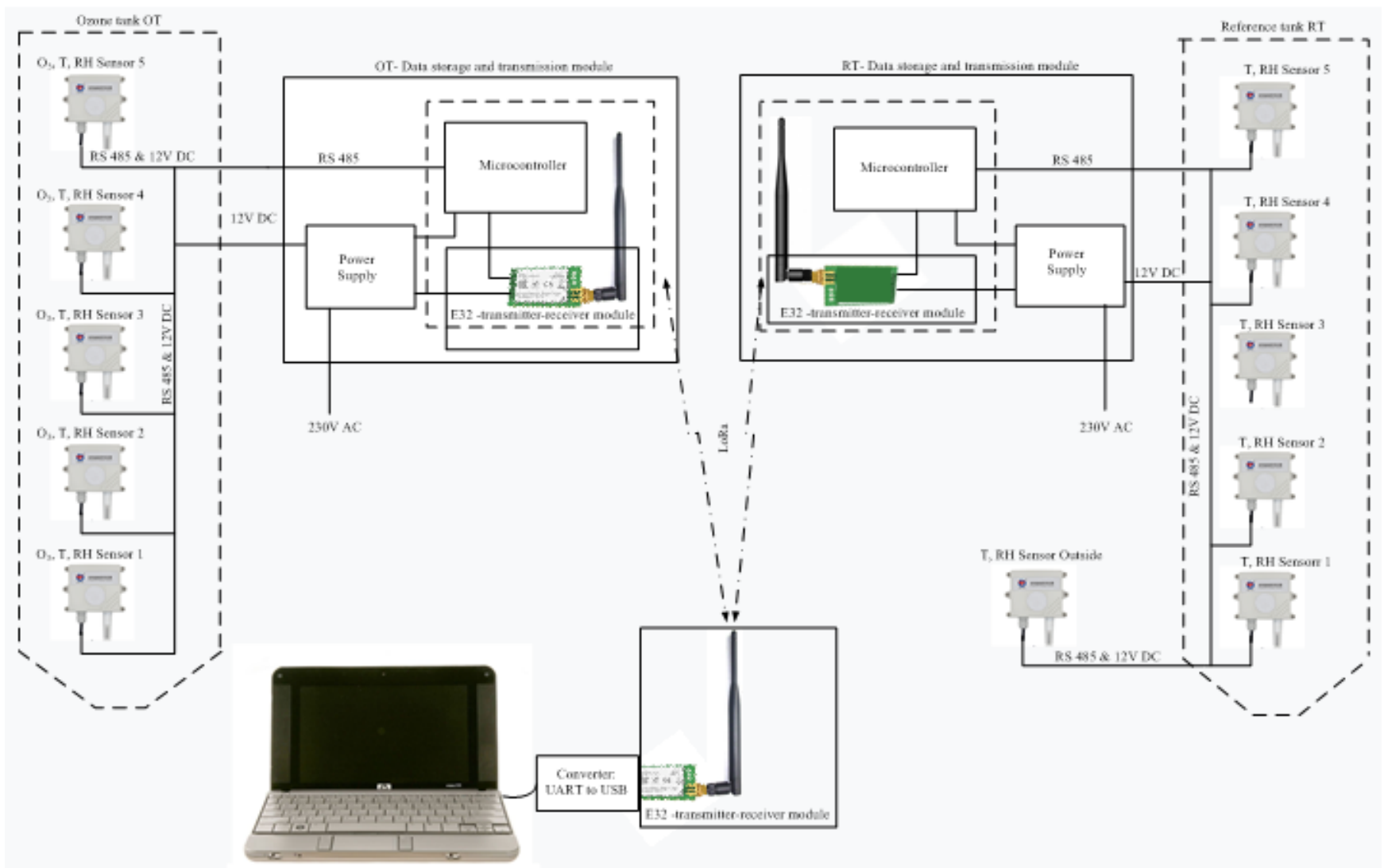

Figure 2. Flowchart (connections diagram) of the control system.

\section{The realization of experiments}

The tanks are loaded with the same amount of purified the same moisture grains and ventilated in one tank with ozone supply to the ventilation air and without ozone supply in the other. Ventilation begins when the relative humidity and temperature of the outside air reach the appropriate equilibrium humidity of grains and ends when humidity is approaching a critical point. During selected period (July - August) the ventilation was possible most often between 11:00 and 21:30. At night the fans were turned off. The data about all parameters (relative humidity in the inter-grain space, temperature and ozone concentration in the different grain layers of the tanks, outdoor humidity and temperature as well as the power consumption of each fan and ozone generator) were recorded in computer.

\section{Results and discussion}

Performance testing of sensor systems took place in production conditions in Tērvete county farm "Mazkalninii" from middle of July till the end of August 2019. Already for many years the farm has been engaged in post-harvest grain treatment - cleaning, drying, active ventilation and storage.

Changes in the parameters recorded from sensors in the tank with ozone supply are summarized in Figure 3 during one ventilation cycle (one day - August 22, 2019). Summer wheat with an initial moisture content of $14.5 \%$, was load in both tanks up to height $5.30 \mathrm{~m}$ and ventilated. As it is seen from Fig. 1, the sensor system \# 5 were close to the upper limit of the grain layer, and data readings could be similar to ambient air. Ventilation started at 13:00 and switch off at 20:00, ozone generator was switch on at 15:00, and switch off at 19:20.

As can be seen in the graphs of the relative humidity in the inter-grain space Figure 3 (a), the real humidity reduction has occurred only in the first sensor area. Turning on the fan at at 13:00 the humidity initially increases as it passes from the bottom layers of the tank to the sensor, then decreases from $73 \%$ to $67 \%$. In the second, third and fourth sensor areas, due to the short ventilation time, no significant changes in relative humidity have occurred. The fifth sensor, in turn, largely follows the outdoor air sensor because of its position near the air/grain boundary. These results correspond to the described in literature (Berzins, 1984) - at the beginning of ventilation the active humidity reduction occurs only in the lower part of the tank. 


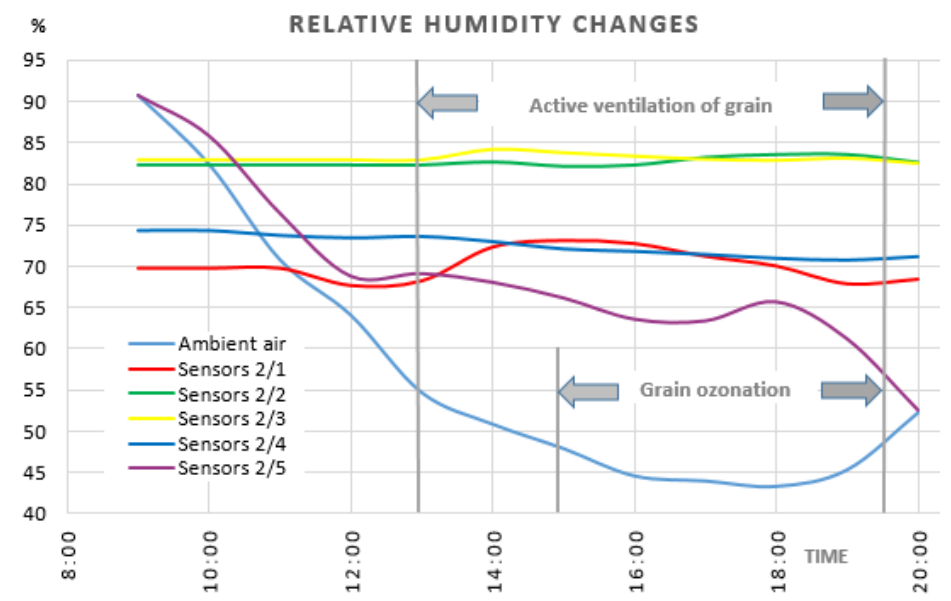

(a)

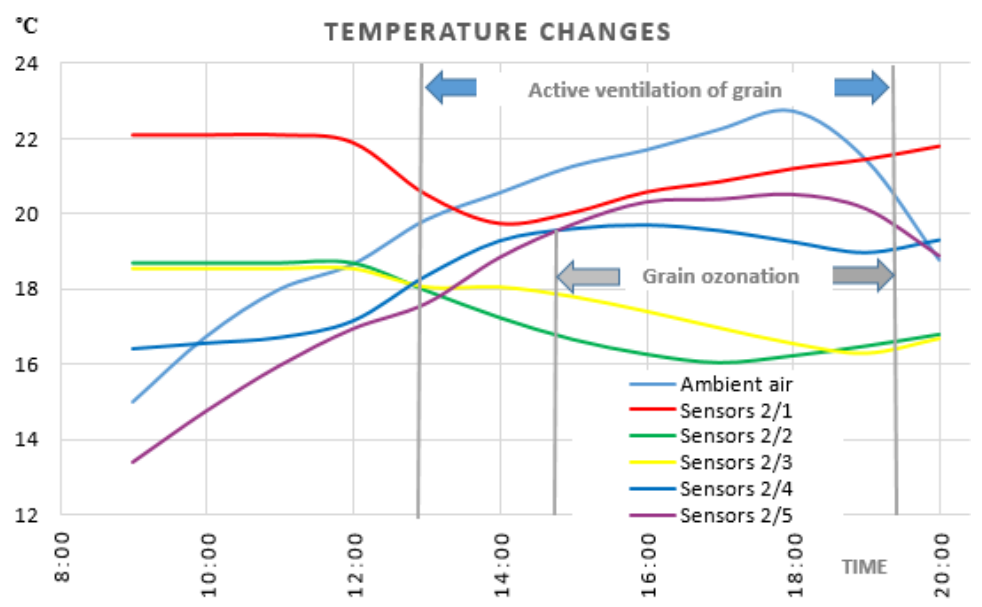

(b)

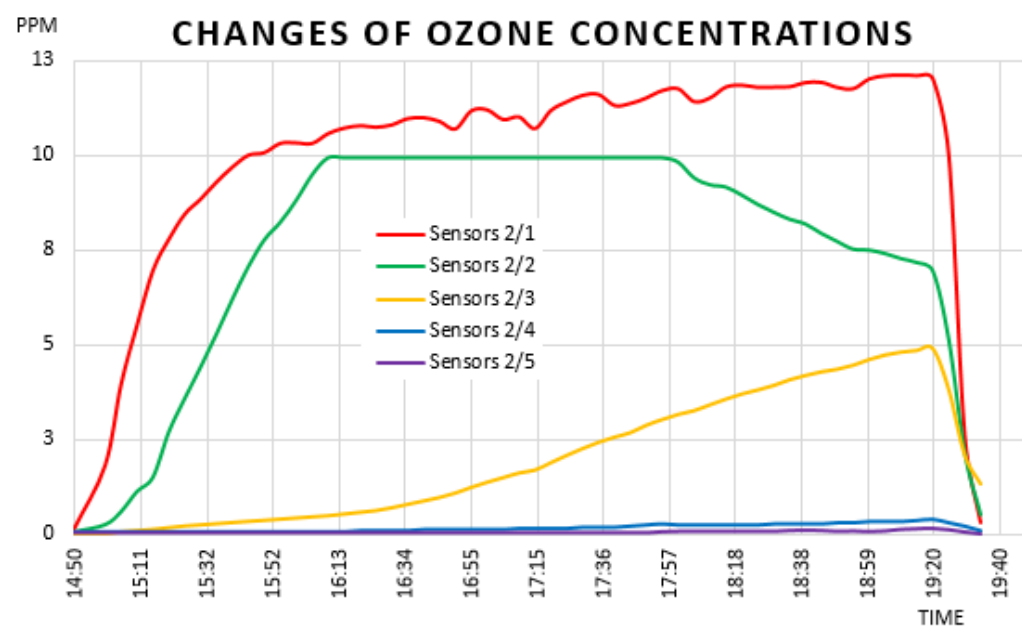

(c)

Figure 3. The changes of sensor readings: $\mathrm{a}-\mathrm{RH}$ changes, $\mathrm{b}$ - temperature changes, $\mathrm{c}-$ ozone concentration changes.

Significant temperature changes (Fig. 3 (b)) have also occurred only in the first sensor area - when the fan is turned on, it falls slightly and then rises continuously in proportion to the increase in the outdoor air temperature. It may also be influenced by the high ozone concentration in the first sensor area. In the second and third sensor areas, the temperature decreases slightly, apparently due to the moisture discharged from the first sensor area. In the fifth sensor zone, the temperature approximates the outdoor air temperature due to its location. 
The ozone concentration (Fig. 3 (c)) increases rapidly during the first hour after the generator is switched on - in the first and second sensor zones, then reaches the maximum in the first sensor zone (above $10 \mathrm{ppm}-$ maximum is $13.5 \mathrm{ppm}$ maximum according to data from first sensor what generator and fan yields). In the second sensor zone, the ozone concentration stabilizes and then falls which could be explained by the intense ozone capture in the first sensor area. In literature (Trockaja, 1998) described that peak ozone uptake occurs within the first 3-4 hours. In the third zone, ozone concentrations gradually increase, while the fourth and fifth sensor zones receive a small amount of ozone. This is confirmed by measurements with a digital hand tool - the concentration of ozone above the grain layer is a few tenths of a ppm.

Studies should be continued to evaluate the effects of ozone on grain ventilation by treating a thinner grain layer of 3.0-3.5 $\mathrm{m}$ what is planned for next year. Sensor systems worked without failures, especially important in production conditions was the ability to control grain temperature in tanks of layers with high grain initial moisture content - above $20-21 \%$. Preliminarily estimation shows that use of ozone in a short ventilation cycle (2-3 days) allows the grain moisture content in the lower layers of the tank to be reduced by $1 \%$ more compared to ozone-free ventilation.

\section{CONCLUSIONS}

Developed and installed sensor system allows to follow the most important parameters of drying process in different layers of grain tank - temperature and humidity. Integrated sensor systems is preferred due to installation and data interpretation considerations. The integration of all 3 sensors into one system is considered an advantage in assessing the effects of ozone on the grain during drying.

Data from sensors are collected by microcontroller, each for every tank. The transmitter-receiver module is used for wireless data transfer between the microcontroller and the computer. When the computer is on, the data collected by the microcontroller is transferred to the computer every $10 \mathrm{~s}$. The viewer program works with a date base and allows see changes in the parameters of the specified sensors in real time mode or during the specified time intervals in the table and graph presentation as well can be transferred to Excel.

Acknowledgements. The financial support of Rural Support Service project No 18-00-A01620-000003 "Technology development of grain drying with active ventilation using ozone" is greatly acknowledged. The authors thank the support and active cooperation the representatives of farm "Mazkalninị” Dr.sc.ing. Aivars Cēsnieks and ing. Sandis Cēsnieks.

\section{REFERENCES}

1. Avdeeva V., Zorina E., Bezgina J., Kolosova O. 2018. Influence of ozone on germination and germinating energy of winter wheat seeds. Engineering for Rural Development, Vol. 17, pp. 543-546. https://doi.org/10.22616/ERDev2018.17.N128

2. Berziņš,E. 1984. Graudu kondicionēšana. “Grain Conditioning”, Rīga, Liesma, pp. 1-41 (In Latvian).

3. Chen C. 2001. Moisture measurement of grain using humidity sensors. Transactions of the ASAE, Vol. 44. https://doi.org/10.13031/2013.6417

4. Emberson L.D., Pleijel H., Ainsworth E.A., Van den Berg M., Ren W., Osborne S., Mills G., Pandey D., Dentener F., Büker P., Ewert F., Koeble R., Van Dingenen R. Ozone effects on crops and consideration in crop models. European Journal of Agronomy, Vol. 100, pp. 19-34. https://doi.org/10.1016/j.eja.2018.06.002

5. Pang X., Shaw M., Lewis A.C. 2017. Electrochemical ozone sensors: A miniaturised alternative for ozone measurements in laboratory experiments and air-quality monitoring. Sensors and Actuators, B Chemical, Vol. 240, pp. 829-837. https://doi.org/10.1016/j.snb.2016.09.020

6. Raila A., Lugauskas A., Steponavičius D., Railienė M., Steponavičienė A., Zvicevičius E. 2006. Application of ozone for reduction of mycological infection in wheat grain. Annals of Agricultural and Environmental Medicine, Vol. 13 (2), pp. $287-294$.

7. Sandhu H. P. S., Manthey F. A., Simsek S. 2012. Ozone gas affects physical and chemical properties of wheat (Triticum aestivum L.) starch. Carbohydrate Polymers, Vol. 87(2), pp. 1261-1268. https://doi.org/10.1016/j.carbpol.2011.09.003

8. Steponavičienė, A., Steponavičius, D., Raila, A., Kemzūraitè, A. (2012) Modelling the ozone penetration in a grain layer. Journal of Environmental Engineering and Landscape Management, 20(4), 292-300. doi:10.3846/16486897.2011.645826 https://doi.org/10.3846/16486897.2011.645826

9. Tiwari B. K., Brennan C. S., Curran T., Gallagher E., Cullen P. J., Donnell C. P. O. 2010. Application of ozone in grain processing. Journal of Cereal Science, Vol. 51(3), pp. 248-255. https://doi.org/10.1016/j.jcs.2010.01.007

10. Trockaja T.P. 1998. Электроактивирование процессов сушки растительных материалов. Автореферат диссертации доктора технических наук. 32c., Москва, ГАУ. Electroactivation of drying processes of plant materials. Abstract of the dissertation of a doctor of technical sciences. 32 pages, Moscow, GAU. (In Russian).

11. Zhu, F. 2018. Effect of ozone treatment on the quality of grain products. Food Chemistry, Vol. 264, pp. 358-366. https://doi.org/10.1016/j.foodchem.2018.05.047 